\title{
SOMATIC AND MOTOR PROFILE OF THE POPULATION AT RISK OF SOCIAL EXCLUSION
}

\author{
Dan BADEA ${ }^{1 *}$ \\ ${ }^{1}$ National University of Physical Education and Sport, Faculty of Physical Education and Sport, Bucharest, Romania \\ *Corresponding author: dan_badea14@yahoo.com
}

DOI: $10.35189 /$ iphm.icpesk.2019.2

\begin{abstract}
This scientific approach aimed to assess the somatic development and motor ability of people (both males and females) at risk of social exclusion in Bucharest and Ilfov County, as well as to make a comparative analysis between the Roma population and the other subjects. This applied research was conducted over a period of 14 months. The 222 subjects participating in the study were represented by 92 young women, of whom 18 Roma subjects, and 130 young men, of whom 44 Roma subjects, aged between 16 and 29 years. The objectification of the research was achieved using a battery made up of 7 assessments and tests, namely: height measurement, body mass measurement, Bouchard index, $10 \times 5$-meter shuttle run test, 30-second push-up test, 30-second sit-up test and Sargent test. Part of the measurements were performed within the project "Strategies for the future, strategies for youth", which has developed sports-based specific methodologies and strategies in order to increase social inclusion and combat exclusion for young people in risk categories due to the economic situation. The research methods used are: scientific documentation, observation, measurement, mathematical and statistical method, graphical method. The research results are reflected in the intrinsic and extrinsic assessment of the somatic and motor potential of the population at risk of social exclusion caused by the economic situation. Thus, this complex assessment process has generated the somatic and motor profile of the population targeted in this scientific paper.
\end{abstract}

Keywords: youth, assessment, Roma people, potential.

\section{Introduction}

Physical education and sport essentially involve social integration, more precisely the practice of specific group activities. Physical education and sport are the best way to come into contact with various people and establish new relationships, which induces relaxation and represents a valuable means to restore energy.

The sports activity reflects a social phenomenon whose importance has grown enormously, engaging large categories of people, becoming more and more practiced and viewed (Dragnea, Bota, \& Stănescu, 2000, p. 148) and being able to produce fundamental changes at the global social level.

This research is part of the project "Strategies for the future, strategies for youth", which has developed sportsbased specific methodologies and strategies in order to increase social inclusion and combat exclusion for young people in risk categories due to the economic situation. Within our scientific approach, we determined the somatic and motor potential of youth, both boys and girls, at risk of social exclusion as a result of the economic situation. The determination was achieved using an optimum strategic plan based on a high level of objectivity and in close correlation with the needs of the population (Grigore, 2011, p. 15).

This assessment, which involves a set of operations and must be regarded as an intrinsic process generating information that has a self-regulatory function in order to increase the efficiency of the proposed programmes (Tudor, 2013, p. 37), has resulted in designing methodologies and strategies specific to sports disciplines, with a view to facilitate the social integration of young people. Based on this assessment, we have also established the somatic and motor profile of the investigated population.

\section{Purpose of the study}

This research aimed to assess the somatic development and motor ability of young people in risk categories due to the economic situation in Bucharest and Ilfov County and also to establish the profiles of the investigated population, both boys and girls, Roma people or not.

\section{Material and Methods}

This applied research was conducted over a 14-month period. The 222 participants were represented by 92 young women, of whom 18 Roma subjects, and 130 young men, of whom 44 Roma subjects, aged 16 to 29 years. The research was objectified using a battery made up of 7 assessments and tests, namely: height measurement, body mass measurement, Bouchard index, 10 x 5-meter shuttle run test, 30-second push-up test, 30-second sit-up 
test and Sargent test. This battery complements the variety of test batteries measuring the motor development of the investigated population, such as those designed by Cazorla (1989) or Soppelsa and Albaret (2005).

The battery consisting of assessments and tests is described below.

- Height measurement

Objective: To determine the height of the subjects

Resources: Stadiometer, tape measure, square

Methodology: The subject stands upright with the legs extended and the back straight (the standing straight position); the heels, intergluteal cleft and spinal column (at the shoulder blade level) touch the stadiometer rod (the wall). The chin of the subject is lowered to the chest so that the upper edge of the external auditory conduct and the eye's external angle are on the same horizontal line. The stadiometer bar is fixed on the top of the head (the square is at a right angle to the wall and the highest point of the head). The height from the skull vertex to feet is measured and the corresponding number on the marker is recorded in meters $(\mathrm{m})$.

Observation: The subject must be barefoot.

- Body mass measurement

Objective: To determine the body mass of the subjects

Resources: Electronic scale

Methodology: The subject stands relaxed on the electronic scale. The body mass is recorded in kilograms (kg).

Observation: The subject must wear light clothing.

- Body mass index measurement

Objective: To determine the ratio of weight to height

Resources: Computer

Methodology: It is calculated by dividing weight in kilograms by height in metres squared.

- 10 x 5-m shuttle run test

Objective: To measure running speed and coordination

Resources: A flat running track having $5 \mathrm{~m}$ in length and $1 \mathrm{~m}$ in width is marked at both ends with parallel 1-m long lines. The ground must be cleaned before performing the test in order to prevent any injuries. At the ends of the running track, an extra space of at least $2 \mathrm{~m}$ to a possible obstacle (fence, wall) is required so that the subject can safely turn while running. A timer and 4 cones are also used as resources.

Methodology: From standing, with a free start, the subject must run 10 times the $5 \mathrm{~m}$ distance at full speed. The changes of direction occur beyond the marking line that exists at each end. The timekeeper is placed sideways, $10 \mathrm{~m}$ away from the track, and starts the stopwatch when the runner's rear leg pushes up off the ground.

- 30" push-up test

Objective: To measure strength and endurance in the upper body

Resources: Flat surface of $2 \mathrm{~m} / 1 \mathrm{~m}$, timer

Methodology: From lying prone, with the legs and palms against the ground, the body stretched and the eyes looking forward, the subject bends the arms until his/her chest gets close (no more than $10 \mathrm{~cm}$ ) to the ground, and then returns to the starting position. The maximum number of repetitions performed within 30 seconds is recorded in the sheet. Only one series of repetitions is allowed.

Observation: Incorrect executions are not counted.

- 30 " sit-up test

Objective: To measure strength and endurance in the abdominal muscles

Resources: Flat surface of $2 \mathrm{~m} / 1 \mathrm{~m}$, gym mat, fitness mat, timer

Methodology: From lying supine, with both hands behind the head, the feet flat on the ground, knees half-bent and legs apart, the subject performs as many sit-ups as possible within 30 seconds. An execution is considered to be correct when the shoulders touch the mat and the elbows touch the knees. The maximum number of repetitions performed within 30 seconds is recorded in the sheet. Only one series of repetitions is allowed.

Observation: To fix the feet on the ground, the subject will be helped by a classmate or will anchor his/her feet under the last step of a stall bar. Incorrect executions are not taken into account.

- Sargent test

Objective: To measure the leg muscle power

Resources: Flat ground surface, a wall vertically marked every 5 centimetres

Methodology: Two measurements are performed:

1. when the subject is on the ground next to the wall, with the arm raised in maximum extension; 
2. when the subject, placed $30 \mathrm{~cm}$ away from the wall, performs three jumps from a half-bent position. The extended arm marks the peak of the jump site on the wall. The best jump is recorded, of which the first measurement will be deducted, by scoring the difference that will represent an assessment criterion.

Observation: The jumps are performed consecutively, with a break of no more than 5" between executions.

The research methods used are: scientific documentation, observation, measurement, mathematical and statistical method, graphical method.

In order to highlight whether the differences between the means obtained by the two categories of subjects are significant, the statistical processing also includes the calculation of Z-test for a 95\% confidence interval.

\section{Results}

The analysis of results collected from the investigated group reveals that:

- The central tendency values indicate a population with a moderate somatic development, especially in terms of height, and an optimal ratio between body mass and height for the female subjects. As regards motor ability, the group shows modest values in the strength tests, this downward trend in the results being also highlighted in previous studies by Stănescu, Ciolcă and Stoicescu (2015). In the other tests involving speed, the results are unsatisfactory for the male population, and for the female population, the results are satisfactory for speed-coordination and unsatisfactory for speed-strength;

- The distribution of results around the mean shows positive asymmetry in most tests and assessments, which is a positive phenomenon, except for the $10 \times 5-\mathrm{m}$ run test and the body mass measurement. The 30 " sit-up test indicates a relatively balanced distribution for boys, and the Sargent test indicates negative asymmetry, which, correlated with the unsatisfactory mean, reflects a worrying situation in the case of girls;

- For the group of young boys, the homogeneity is different throughout the assessment; thus, the level of homogeneity is higher for the height measurement and the $10 \times 5-\mathrm{m}$ run test, there is a lack of homogeneity for the 30" push-up test, and the homogeneity is moderate in the other tests. For the group of young girls, the homogeneity is also different throughout the assessment; thus, the level of homogeneity is good for the somatic measurements, it is moderate for the $10 \times 5-\mathrm{m}$ run test and the Sargent test, and there is a lack of homogeneity for the 30" push-up test and the 30" sit-up test.

Tables 1 and 2 show the overall results achieved by the investigated girls and boys.

Table 1. Overall results - Girls

\begin{tabular}{lccccccc}
\hline & $\begin{array}{c}\text { Body mass } \\
(\mathrm{kg})\end{array}$ & $\begin{array}{c}\text { Height } \\
(\mathrm{cm})\end{array}$ & $\begin{array}{c}\text { Body mass } \\
\text { index }\end{array}$ & $\begin{array}{c}\text { 10 x 5-m run } \\
(\mathrm{s})\end{array}$ & $\begin{array}{c}\text { 30" push-ups } \\
(\mathrm{reps})\end{array}$ & $\begin{array}{c}\text { 30" sit-ups } \\
(\mathrm{reps})\end{array}$ & $\begin{array}{c}\text { Sargent test } \\
(\mathrm{cm})\end{array}$ \\
\hline Mean & 57.01 & 166.02 & 34.33 & 18.93 & 14.65 & 21.83 & 29.62 \\
Max & 86.00 & 181.00 & 53.75 & 28.85 & 35.00 & 38.00 & 40.00 \\
S & 6.80 & 7.33 & 3.87 & 1.89 & 7.59 & 6.12 & 5.71 \\
Min & 37.00 & 152.00 & 24.18 & 16.20 & 0.00 & 10.00 & 11.00 \\
Cv & 11.93 & 4.41 & 11.26 & 9.96 & 51.78 & 28.04 & 19.27 \\
\hline
\end{tabular}

Table 2. Overall results - Boys

\begin{tabular}{lccccccc}
\hline & $\begin{array}{c}\text { Body mass } \\
(\mathrm{kg})\end{array}$ & $\begin{array}{c}\text { Height } \\
(\mathrm{cm})\end{array}$ & $\begin{array}{c}\text { Body mass } \\
\text { index }\end{array}$ & $\begin{array}{c}\text { 10 x 5-m run } \\
(\mathrm{s})\end{array}$ & $\begin{array}{c}\text { 30" push-ups } \\
(\text { reps })\end{array}$ & $\begin{array}{c}\text { 30" sit-ups } \\
(\text { reps })\end{array}$ & $\begin{array}{c}\text { Sargent test } \\
(\mathrm{cm})\end{array}$ \\
\hline Mean & 67.46 & 174.58 & 38.60 & 17.64 & 27.63 & 28.16 & 37.58 \\
Max & 107.00 & 191.00 & 56.02 & 22.60 & 48.00 & 42.00 & 70.00 \\
S & 9.30 & 6.43 & 4.70 & 1.46 & 7.06 & 5.34 & 6.65 \\
Min & 50.00 & 162.00 & 28.34 & 14.12 & 2.00 & 15.00 & 15.00 \\
Cv & 13.78 & 3.68 & 12.17 & 8.27 & 25.57 & 18.96 & 17.70 \\
\hline
\end{tabular}

The comparative analysis of results obtained by the two groups of subjects reveals that:

- The average values for boys and girls, in terms of motor development, are significantly higher than those achieved by the Roma population. This difference might be associated with the subjects' eating habits 
and lifestyles (Rich-Edwards et al., 1994; Stevens et al., 1998). The average scores for motor ability are also favourable to boys and girls compared to the Roma population, except for the Sargent test, where the value recorded by Roma boys is higher;

- The Z-test scores obtained by the male population certify a significant difference between the means of the two samples only for the somatic assessments, not the motor tests, where the differences are not significant. The Z-test scores achieved by the female population certify a significant difference between the means of the two samples for the height measurements, the $10 \times 5-\mathrm{m}$ run test and the 30 " sit-up tests, while in the other tests, the differences are not significant;

- Regarding the distribution of results around the mean, we notice a similarity for both groups in most tests. For the male population, the exceptions are the $10 \times 5-\mathrm{m}$ run test and the Sargent test, where the grouping of results is in favour of the boys; for the female population, the push-up test reveals a positive distribution in favour of the Roma girls, while for the Sargent test, the grouping of results is in favour of the girls;

- Concerning the female population, the coefficient of variation (Cv) indicates a higher level of homogeneity for the group of girls compared to the group of Roma girls in all tests. It should also be mentioned the lack of homogeneity of both groups in the strength tests. Concerning the male population, the coefficient of variation indicates a higher level of homogeneity for the group of boys compared to the group of Roma boys in most tests. In the sit-up test, the level of homogeneity is relatively similar for the two groups. In the Sargent test, the homogeneity is better for the group of Roma boys.

Tables 3 to 8 show the results achieved by the investigated girls and boys.

Table 3. Results - Girls

\begin{tabular}{lccccccc}
\hline & $\begin{array}{c}\text { Body mass } \\
(\mathrm{kg})\end{array}$ & $\begin{array}{c}\text { Height } \\
(\mathrm{cm})\end{array}$ & $\begin{array}{c}\text { Body mass } \\
\text { index }\end{array}$ & $\begin{array}{c}\text { 10 x 5-m run } \\
(\mathrm{s})\end{array}$ & $\begin{array}{c}\text { 30" push-ups } \\
(\mathrm{reps})\end{array}$ & $\begin{array}{c}\text { 30" sit-ups } \\
(\mathrm{reps})\end{array}$ & $\begin{array}{c}\text { Sargent test } \\
(\mathrm{cm})\end{array}$ \\
\hline Mean & 57.19 & 166.89 & 34.27 & 18.56 & 15.20 & 22.77 & 30.16 \\
Max & 79.00 & 181.00 & 50.00 & 24.06 & 27.00 & 38.00 & 40.00 \\
$\mathrm{~S}$ & 5.97 & 7.48 & 3.32 & 1.39 & 6.42 & 5.73 & 5.21 \\
Min & 45.00 & 152.00 & 28.30 & 16.20 & 0.00 & 11.00 & 20.00 \\
$\mathrm{Cv}$ & 10.44 & 4.48 & 9.69 & 7.50 & 42.25 & 25.16 & 17.28 \\
\hline
\end{tabular}

Table 4. Results - Roma girls

\begin{tabular}{lccccccc}
\hline & $\begin{array}{c}\text { Body mass } \\
(\mathrm{kg})\end{array}$ & $\begin{array}{c}\text { Height } \\
(\mathrm{cm})\end{array}$ & $\begin{array}{c}\text { Body mass } \\
\text { index }\end{array}$ & $\begin{array}{c}\text { 10 x 5-m run } \\
(\mathrm{s})\end{array}$ & $\begin{array}{c}\text { 30" push-ups } \\
(\mathrm{reps})\end{array}$ & $\begin{array}{c}\text { 30" sit-ups } \\
(\text { reps })\end{array}$ & $\begin{array}{c}\text { Sargent test } \\
(\mathrm{cm})\end{array}$ \\
\hline Mean & 56.28 & 162.44 & 34.61 & 20.45 & 12.39 & 17.94 & 27.39 \\
Max & 86.00 & 171.00 & 53.75 & 28.85 & 35.00 & 29.00 & 39.00 \\
S & 9.68 & 5.54 & 5.71 & 2.76 & 11.15 & 6.30 & 7.15 \\
Min & 37.00 & 153.00 & 24.18 & 17.22 & 0.00 & 10.00 & 11.00 \\
Cv & 17.20 & 3.41 & 16.51 & 13.52 & 89.97 & 35.11 & 26.12 \\
\hline
\end{tabular}

Table 5. Summary table of average scores - Girls

\begin{tabular}{lccccccc}
\hline & $\begin{array}{c}\text { Body mass } \\
(\mathrm{kg})\end{array}$ & $\begin{array}{c}\text { Height } \\
(\mathrm{cm})\end{array}$ & $\begin{array}{c}\text { Body mass } \\
\text { index }\end{array}$ & $\begin{array}{c}10 \times \text { x 5-m run } \\
(\mathrm{s})\end{array}$ & $\begin{array}{c}\text { 30" push-ups } \\
(\text { reps })\end{array}$ & $\begin{array}{c}\text { 30" sit-ups } \\
(\text { reps })\end{array}$ & $\begin{array}{c}\text { Sargent } \\
\text { test }(\mathrm{cm})\end{array}$ \\
\hline Girls & 57.19 & 166.89 & 34.27 & 18.56 & 15.20 & 22.77 & 30.16 \\
Total & $\mathbf{5 7 . 0 1}$ & $\mathbf{1 6 6 . 0 2}$ & $\mathbf{3 4 . 3 3}$ & $\mathbf{1 8 . 9 3}$ & $\mathbf{1 4 . 6 5}$ & $\mathbf{2 1 . 8 3}$ & $\mathbf{2 9 . 6 2}$ \\
Roma girls & 56.28 & 162.44 & 34.61 & 20.45 & 12.39 & 17.94 & 27.39 \\
Z-Test & 0.38 & 2.83 & -0.24 & -2.81 & 1.02 & 2.96 & 1.54 \\
\hline
\end{tabular}

Table 6. Results - Boys

\begin{tabular}{ccccccc}
\hline $\begin{array}{c}\text { Body mass } \\
(\mathrm{kg})\end{array}$ & $\begin{array}{c}\text { Height } \\
(\mathrm{cm})\end{array}$ & $\begin{array}{c}\text { Body mass } \\
\text { index }\end{array}$ & $\begin{array}{c}10 \times 5 \text {-m run } \\
(\mathrm{s})\end{array}$ & $\begin{array}{c}30 \text { ” push-ups } \\
(\mathrm{reps})\end{array}$ & $\begin{array}{c}30 \text { ” sit-ups } \\
(\mathrm{reps})\end{array}$ & $\begin{array}{c}\text { Sargent test } \\
(\mathrm{cm})\end{array}$ \\
\hline
\end{tabular}


International Proceedings of Human Motricity/ ICPESK 2019

Supplementary Issue of Discobolul - Physical Education, Sport and Kinetotherapy Journal, 2019

\begin{tabular}{lccccccc}
\hline Mean & 69.07 & 175.51 & 39.31 & 17.54 & 28.22 & 28.67 & 37.48 \\
Max & 107.00 & 191.00 & 56.02 & 21.69 & 48.00 & 42.00 & 70.00 \\
S & 9.55 & 6.24 & 4.76 & 1.35 & 7.04 & 5.42 & 7.39 \\
Min & 53.00 & 164.00 & 28.34 & 14.12 & 4.00 & 15.00 & 15.00 \\
Cv & 13.82 & 3.56 & 12.11 & 7.69 & 24.93 & 18.92 & 19.73 \\
\hline
\end{tabular}

Table 7. Results - Roma boys

\begin{tabular}{lccccccc}
\hline & $\begin{array}{c}\text { Body mass } \\
(\mathrm{kg})\end{array}$ & $\begin{array}{c}\text { Height } \\
(\mathrm{cm})\end{array}$ & $\begin{array}{c}\text { Body mass } \\
\text { index }\end{array}$ & $\begin{array}{c}\text { 10 x 5-m run } \\
(\mathrm{s})\end{array}$ & $\begin{array}{c}\text { 30" push-ups } \\
(\text { reps })\end{array}$ & $\begin{array}{c}\text { 30" sit-ups } \\
(\text { reps })\end{array}$ & $\begin{array}{c}\text { Sargent test } \\
(\mathrm{cm})\end{array}$ \\
\hline Mean & 64.32 & 172.75 & 37.22 & 17.82 & 26.48 & 27.16 & 37.80 \\
Max & 86.10 & 190.00 & 49.20 & 22.60 & 39.00 & 39.00 & 47.00 \\
S & 7.99 & 6.46 & 4.29 & 1.65 & 7.06 & 5.08 & 4.96 \\
Min & 50.00 & 162.00 & 30.06 & 15.22 & 2.00 & 16.00 & 27.00 \\
Cv & 12.43 & 3.74 & 11.54 & 9.24 & 26.66 & 18.71 & 13.12 \\
\hline
\end{tabular}

Table 8. Summary table of average scores - Boys

\begin{tabular}{lccccccc}
\hline & $\begin{array}{c}\text { Body mass } \\
(\mathrm{kg})\end{array}$ & $\begin{array}{c}\text { Height } \\
(\mathrm{cm})\end{array}$ & $\begin{array}{c}\text { Body mass } \\
\text { index }\end{array}$ & $\begin{array}{c}10 \times \text { x-m run } \\
(\mathrm{s})\end{array}$ & $\begin{array}{c}\text { 30" push-ups } \\
(\mathrm{reps})\end{array}$ & $\begin{array}{c}\text { 30" sit-ups } \\
(\mathrm{rep})\end{array}$ & $\begin{array}{c}\text { Sargent } \\
\text { test }(\mathrm{cm})\end{array}$ \\
\hline Boys & 69.07 & 175.51 & 39.31 & 17.54 & 28.22 & 28.67 & 37.48 \\
Total & $\mathbf{6 7 . 4 6}$ & $\mathbf{1 7 4 . 5 8}$ & $\mathbf{3 8 . 6 0}$ & $\mathbf{1 7 . 6 4}$ & $\mathbf{2 7 . 6 3}$ & $\mathbf{2 8 . 1 6}$ & $\mathbf{3 7 . 5 8}$ \\
Roma boys & 64.32 & 172.75 & 37.22 & 17.82 & 26.48 & 27.16 & 37.80 \\
Z-Test & 2.99 & 2.33 & 2.53 & 1.03 & 1.33 & 1.56 & 0.25 \\
\hline
\end{tabular}

Based on the previous analyses, we have established the somatic and motor profiles for each category of population investigated in our research, as follows:

- The male population shows a moderate somatic development, with good values for the speedcoordination skill and moderate values for the speed-strength component. In terms of strength-endurance, the range of values is moderate;

- The boy population shows a moderate somatic development, with good speed-coordination skills and moderate speed-strength, and regarding the strength-endurance skill, the values are moderate to good. We mention that the boy population profile is, for all parameters, superior to the male population profile;

- The Roma boy population profile denotes a poor-to-moderate somatic development, with values below the male population profile. In terms of skills, speed-coordination falls within a moderate-to-good level, the values are moderate for speed-strength, but in the context of a narrower gap than in the case of boy population profile, and for strength-endurance, the profile reveals poor-to-moderate values, which are lower compared to the male population profile and the boy population profile;

- The female population shows a moderately balanced somatic profile. The skill profile for speedcoordination is good, it is poor to moderate for speed-strength and poor for strength-endurance;

- In this context, the girl population profile is almost similar to the female population profile. Instead, the Roma girl population profile generally denotes decreased values, with large gaps between the minimum and maximum values.

Table 9 shows the somatic and motor profiles by category of population.

Table 9. Somatic and motor profiles by category of population

\begin{tabular}{|c|c|c|c|c|c|c|c|}
\hline & $\begin{array}{l}\text { Body mass } \\
(\mathrm{kg})\end{array}$ & $\begin{array}{l}\text { Height } \\
(\mathrm{cm})\end{array}$ & $\begin{array}{l}\text { Body mass } \\
\text { index }\end{array}$ & $\begin{array}{c}10 \times 5 \text { m-run } \\
\text { (s) }\end{array}$ & $\begin{array}{l}\text { 30" push-ups } \\
\text { (reps) }\end{array}$ & $\begin{array}{l}\text { 30" sit-ups } \\
\text { (reps) }\end{array}$ & $\begin{array}{l}\text { Sargent test } \\
(\mathrm{cm})\end{array}$ \\
\hline $\begin{array}{l}\text { Boy } \\
\text { population }\end{array}$ & $59.52-78.62$ & $\begin{array}{l}169.27- \\
181.75\end{array}$ & $34.55-44.07$ & $16.19-18.89$ & $21.18-35.26$ & $\begin{array}{l}23.25- \\
34.09\end{array}$ & $30.09-44.87$ \\
\hline $\begin{array}{l}\text { Male } \\
\text { population }\end{array}$ & 58.16-76.76 & $\begin{array}{l}168.15- \\
181.01\end{array}$ & $33.90-43.30$ & 16.18-19.10 & 20.57-34.69 & $\begin{array}{c}22.82- \\
33.50\end{array}$ & $30.93-44.23$ \\
\hline Roma boy & $56.33-72.31$ & 166.29- & $32.93-41.51$ & $16.17-19.47$ & $19.42-33.54$ & 22.08- & $32.84-42.76$ \\
\hline
\end{tabular}


International Proceedings of Human Motricity/ ICPESK 2019

Supplementary Issue of Discobolul - Physical Education, Sport and Kinetotherapy Journal, 2019

\begin{tabular}{|c|c|c|c|c|c|c|c|}
\hline population & & 179.21 & & & & 32.24 & \\
\hline $\begin{array}{l}\text { Girl } \\
\text { population }\end{array}$ & $51.22-63.16$ & $\begin{array}{c}159.41- \\
174.37\end{array}$ & $30.95-37.59$ & $17.17-19.95$ & $8.78-21.62$ & $\begin{array}{l}17.04- \\
28.50\end{array}$ & $24.95-35.37$ \\
\hline $\begin{array}{l}\text { Female } \\
\text { population }\end{array}$ & $50.21-63.81$ & $\begin{array}{c}158.69- \\
173.35\end{array}$ & $30.46-38.20$ & $17.04-20.82$ & $7.06-22.24$ & $\begin{array}{l}15.71- \\
27.95\end{array}$ & 23.91-35.33 \\
\hline $\begin{array}{l}\text { Roma girl } \\
\text { population }\end{array}$ & $46.60-65.96$ & $\begin{array}{c}156.90- \\
167.98\end{array}$ & $28.90-40.32$ & $17.69-23.21$ & $1.24-23.54$ & $\begin{array}{l}11.64- \\
24.24\end{array}$ & $20.24-34.54$ \\
\hline
\end{tabular}

\section{Conclusion}

Following the recording, processing and interpretation of data, we can state that:

- The central tendency values reflect higher values of the somatic component for girls and boys compared to the Roma population. This phenomenon is also found in the case of the motor component. Thus, we can say that the assessed Roma population is, from a somatic and motor point of view, below the values of the other participants;

- It should also be mentioned that the differences between the Roma girl population and the other girls are significant in $50 \%$ of the tests, and those between the Roma boy population and the other boys are significant only somatically, not in motor terms;

- The distribution of results around the mean generally reflects positive aspects; they are grouped in the area of values above the average, except for the $10 \times 5-\mathrm{m}$ run test, where the average is positioned to the right, which is not beneficial;

- As regards the level of homogeneity, it is noted that, in somatic terms, the group has high homogeneity for girls and moderate for boys, and in motor terms, the group has moderate and high levels of homogeneity for the $10 \times 5-\mathrm{m}$ run test and the Sargent test, in contrast to the strength tests, where the homogeneity is low or there is even a lack of homogeneity;

- The profiles, which have been the purpose of this research, reflect a young population with modest values in somatic terms and satisfactory in terms of motricity. In this context, we can state that the target population of this study has a somatic development around the average, but low motor potential, especially for the strength component.

\section{References}

Cazorla, G. (1989). L'évaluation des capacités motrices - De l'itinéraire d'un concept à l'élaboration d'un outil [The assessment of motor skills - From the route of a concept to the development of a tool]. Revue Française de Pédagogie, 89, 15-22. https://doi.org/10.3406/rfp.1989.1401

Dragnea, A., Bota, A., \& Stănescu, M. (2000). Teoria educației fizice şi sportului [Theory of physical education and sport]. București: Cartea Școlii.

Grigore, Gh. (2011). Fotbal: Strategia formativă a jucătorului [Football: Formative strategy of the player]. București: Printech.

Rich-Edwards, J. W, Goldman, M. B, Willet, W. C., Hunter, D. J., Stampfer, M. J., Colditz, G. A., \& Manson, J. E. (1994). Adolescent body mass index and infertility caused by ovulatory disorder. American Journal of Obstetrics and Gynecology, 171(1), 171-177. https://doi.org/10.1016/0002-9378(94)90465-0

Soppelsa, R., \& Albaret, J. M. (2005). La batterie d'évaluation du mouvement chez l'enfant (M-ABC): Étalonnage sur une population d'enfants de 4 à 12 ans [The Movement Assessment Battery for Children - M-ABC: Calibration on a child population aged 4 to 12 years]. Psychomotricité, 195-200. Retrieved from https://docplayer.fr/78990640-La-batterie-d-evaluation-du-mouvement-chez-l-enfant-m-abc-etalonnage-surune-population-d-enfants-de-4-a-12-ans.html

Stănescu, M., Ciolcă, C., \& Stoicescu, M. (2015). Study of the motor aptitudes of the children in North-Eastern Romania. Paper presented at the $6^{\text {th }}$ Lumen International Scientific Conference "Rethinking Social Action. Core Values", 16-19 April 2015, Iași.

Stevens, J., Cai, J., Pamuk, E. R., Williamson, D. F., Thun, M. J., \& Wood, J. L. (1998). The effect of age on the association between body mass index and mortality. The New England Journal of Medicine, 338(1), 1-7. https://doi.org/10.1056/NEJM199801013380101

Tudor, V. (2013). Măsurare și evaluare în sport [Measurement and evaluation in sport]. București: Discobolul. 